(RESEARCH ARTICLE)

\title{
Heavy metal accumulation in marine sediments - An assessment in ONGC's platforms in Mumbai High Region, Arabian Sea
}

\author{
Pramod Kumar*, G. L. Das and Atul Garg \\ Environment Division, IPSHEM- ONGC Goa India.
}

World Journal of Advanced Engineering Technology and Sciences, 2021, 02(01), 060-068

Publication history: Received on 06 February 2021; revised on 14 March 2021; accepted on 16 March 2021

Article DOI: https://doi.org/10.30574/wjaets.2021.2.1.0026

\begin{abstract}
Heavy metal pollution, in the aquatic ecosystem, especially sediments, has become an area of concern garnering increasing attention since the past few decades. Some metals like manganese (Mn), copper (Cu), iron (Fe) and zinc ( $\mathrm{Zn})$ are biologically important for marine life, others like lead ( $\mathrm{Pb}$ ), cadmium (Cd), and Arsenic (As) are non-essential and become toxic at higher concentrations. These metals introduced into the marine ecosystem mainly due to anthropogenic activities. These heavy metals when discharged into the marine ecosystem may be absorbed in suspended solids, remain in seawater, etc., but ultimately end up in the sediments which act as a "sink" and later the "source", due to their restricted mobility. Hence, monitoring the heavy metal concentrations in these marine sediments over a period of time is of great help in checking the pollution level and identifying the trend, which in turn will be instrumental in formulating sustainable practices.

The paper mainly focuses on the study of the concentration of non-essential heavy metals in sea sediment around the operational areas of ONGC in western offshore area. The distribution of heavy metals in the sediments of ONGC's exploratory blocks in Mumbai High Region, Arabian Sea was investigated. Surface sediment samples collected from 5 platforms (R-12A, BLQ, NBP, ICP and NQ) of Mumbai High Region, Arabian Sea and digested samples were analyzed by ICP-MS for ${ }^{75} \mathrm{As},{ }^{111} \mathrm{Cd}$ and ${ }^{208} \mathrm{~Pb}$. Comparison of results in studied 5 platforms with various sediment quality guidelines is discussed to assess the present contamination. It reveals that sediments in study area are not contaminated with respect to perceived heavy metals. Generated data will assist in future for proactive measures and minimize the impact of anthropogenic sources.
\end{abstract}

Keywords: Heavy Metal Pollution; Mumbai High; Sediment

\section{Introduction}

Marine environmental pollution is a growing concern today. There are a lot of activities (both anthropogenic as well as natural) that may contribute to marine pollution, E\&P activities of Oil and Gas companies being one of them. ONGC, one of the most valued Maharatnas of India, is committed to adopting sustainable E\&P practices in its offshore installations, in order to protect and preserve our marine ecosystem. Hence, ONGC through its institute IPSHEM, has been conducting regular offshore environmental monitoring in the Western Offshore region. The aim of this study is to paint an overview of the environmental status and trends over time in relation to our offshore E\&P activities- to indicate whether the environmental status is stable, deteriorating or improving.

The study of heavy metals in the marine sediments is particularly important in comparison to other parameters due to their non-biodegradable nature, accumulative properties and long biological half-lives. Heavy metals like lead (Pb), cadmium (Cd), and Arsenic (As) are non-essential and when discharged into the marine ecosystem may be absorbed in

\footnotetext{
${ }^{*}$ Corresponding author: Pramod Kumar

Chemist, Environment Division, IPSHEM- ONGC Goa India.
} 
suspended solids, remain in seawater, etc., but through various physical, chemical or biological mechanisms ultimately end up in the sediments which act as a "sink" and later the "source", due to their restricted mobility. They are potential threats to the ecosystem because they could be concentrated and biomagnified at sufficiently high concentrations, and sometimes be converted to more toxic organic compounds. Therefore, the distribution of such toxic metals in sediments, over a period of time, might provide evidence for human activities and their effects on the marine ecosystem. For this reason, sediments are most commonly chosen as environmental indicators of the quality and potential risks within aquatic systems.

The study is intended to determine the present level of three metals ( $\mathrm{As}, \mathrm{Pb}$, and $\mathrm{Cd}$ ) concentrations in sediments of $\mathrm{R}$ 12A, BLQ, NBP, ICP and NQ of Mumbai High Region, Arabian Sea. Pollution status of collected sediments was assessed by comparing with sediment quality guidelines (SQG). Marine environmental researchers use SQGs as useful tool to assess quality and toxicology of sediments as they provide comprehensive assessment. The results of this study, can be considered as base-line data, will help for proactive measurements to manage and control pollution in coastal region. Thus, study is vital so that any change caused by anthropogenic sources over a period of time can be monitored and managed.

\section{Study Area}

Mumbai High Region, Arabian Sea is considered significant address for oil and gas reserves. The study area extends from $18^{\circ} 16^{\prime} 20.32^{\prime \prime} \mathrm{N}$ to $19^{\circ} 34^{\prime} 15.00^{\prime \prime} \mathrm{N}$ and $71^{\circ} 1^{\prime} 40.59^{\prime \prime E}$ to $72^{\circ} 22^{\prime} 48.52^{\prime \prime E}$.

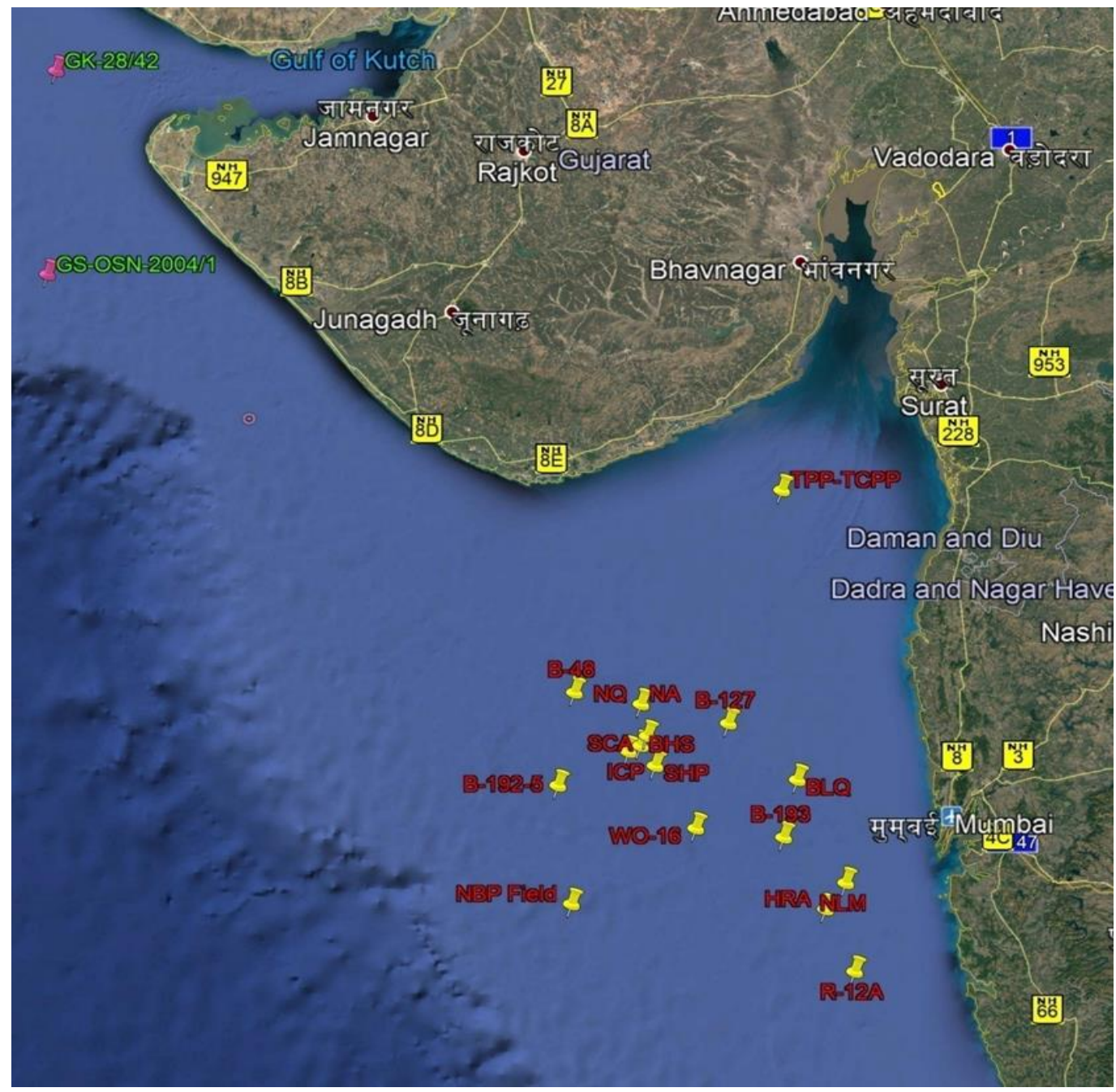

Figure 1 Map showing the location of sampling stations in the study area of Western offshore 
OSPAR (Oslo and Paris) Commission Guidelines [2] have been followed, as shown in Figure 2.

A Van Veen Grab of $25 \mathrm{~cm}$ x $30 \mathrm{~cm}$ dimension and approximately $1.5 \mathrm{~kg}$ capacity having a penetration depth of $10 \mathrm{~cm}$ was used for collection of sediments, from the sampling vessel. This medium version of the grab was used to prevent likely damage to pipelines etc. in case of any accidental strike on flow lines. Prior to deployment, the grab was cocked with the safety key in place. The grab was then hoisted over the side, the safety key was removed, and the grab was lowered at $2 \mathrm{~m} / \mathrm{sec}$ until it was $5 \mathrm{~m}$ above the bottom. From this point, it was lowered at $1 \mathrm{~m} / \mathrm{sec}$ to minimize the effects of bow wave disturbance. After bottom contact had been made (indicated by slack in the lowering wire), the tension on the wire was slowly increased, causing the lever arms to close the grab. Once the grab was back on board, the top doors were opened for inspection.

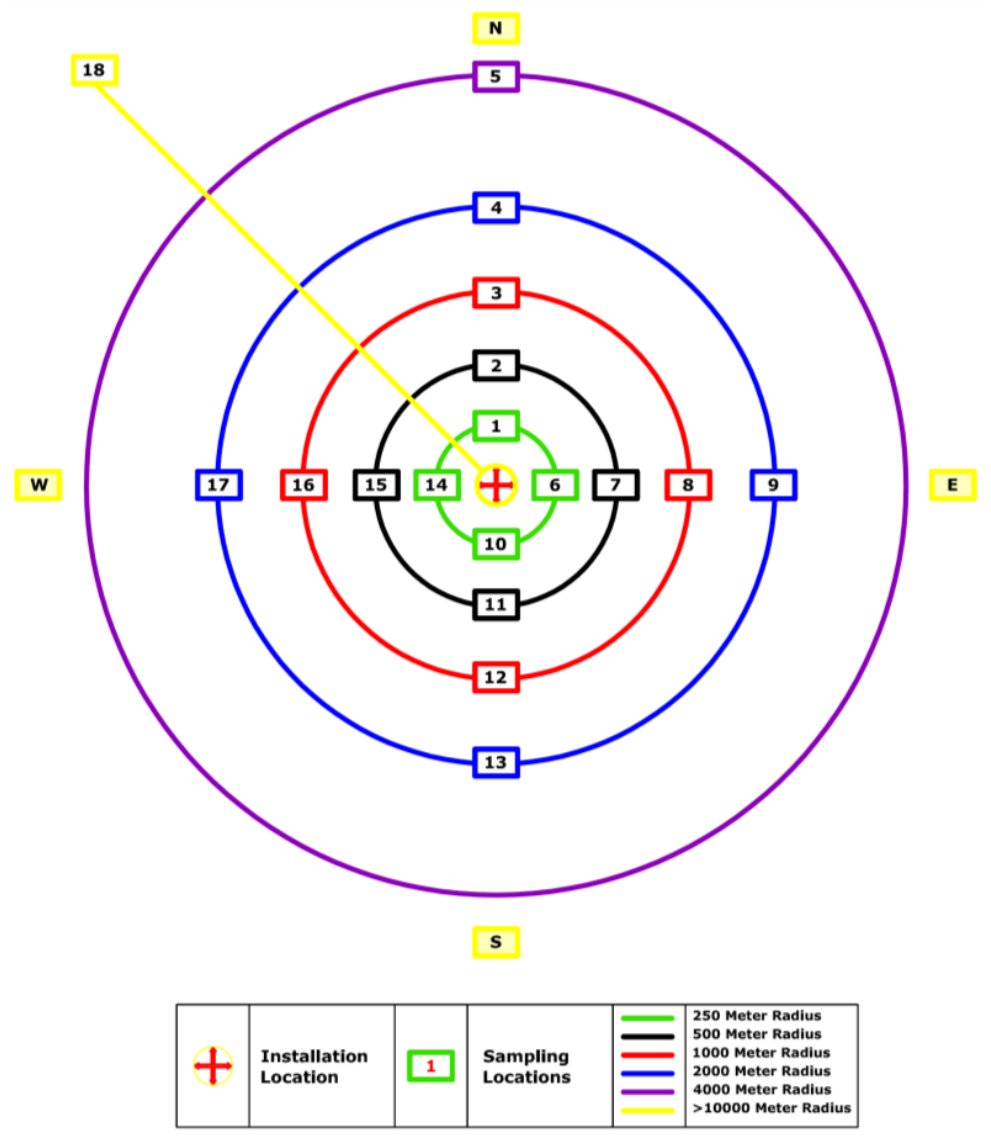

Figure 2 OSPAR Commission Sampling Strategy

\subsection{Procedure for Sample Analysis}

From the bulk sediment, a representative subsample was transferred to an oven and dried at $50 \pm 2 \stackrel{\circ}{ }{ }^{\circ}$. The homogenized samples were then ground to powder in granite mortar with a pestle and kept in a pre-cleaned container for further analysis. Trace metal extraction was carried out following the standard method EPA 3052. Approximately $200 \mathrm{mg}$ of homogeneous sediment sample was digested with $6 \mathrm{~mL}$ of nitric acid and $3 \mathrm{~mL}$ of perchloric acid in Teflon vessels for 50 minutes using a closed microwave reaction system (Perkin Elmer, Titan MPS). After cooling the vessel completely, dissolved samples were then filtered through Whatman filter paper and diluted to $25 \mathrm{~mL}$ with milli Q water. The extract was stored in polythene bottles at $4^{\circ} \mathrm{C}$ for the analysis of trace metals. In order to obtain more accurate data, all the glassware and Teflon sample cups in this study were soaked with $5 \%$ nitric acid, rinsed with milli-Q water, and dried to eliminate potential contamination.

An inductively coupled plasma mass spectrometer (ICP-MS; model Agilent 7700) was used for determination of trace metals concentration. Background correction and matrix interference were monitored throughout the analysis. The accuracy was examined by analyzing all samples in duplicate. The analytical concentrations of the selected metals of our interest were listed in Table 2. 


\section{Results and Discussion}

The sediments of the present study area were mainly composed of clay-silt ( $>90 \%)$ with varied proportions of clay (29$52 \%)$, silt (35-49\%) and sand (10-12\%). Silt and clay were the dominant textural class at all the sampling locations. Relative high ratio of sand in comparison with deep ocean platforms in Arabian Sea may be due to lower water depths and enormous river influx. In this study, the concentrations of selected Three heavy metals in sediments were measured (Table 2). These three metals Lead (Pb), Arsenic (As), and Cadmium (Cd) cause a serious threat to aqua system at higher concentration.

In the present investigation, average concentrations of different platforms in sediments of present study area varied from 4.16 to $9.35 \mathrm{mg} \mathrm{kg}^{-1}$ for Arsenic, 0.08 to $0.15 \mathrm{mg} \mathrm{kg}^{-1}$ for Cadmium, and 1.92 to $10.45 \mathrm{mg} \mathrm{kg}^{-1}$ for Lead. It is noticed that the distribution of metal concentrations in the sediments of study area has not followed particular trend as concentration varied from one location to another but variation is found minimum when area, depth, and other oceanographic parameters are concerned. It was also documented that all measured metals were found nearly uniformly distributed across all the sampling sites.

These obtained metal concentrations were compared with sediment quality guidelines to assess present marine pollution status with respect to perceived metals and impact of industrial and economic activities in this area. Table 3 shows guidelines used in present study; sediment criteria proposed by EPA, CBSOG Consensus-Based Sediment Quality Guidelines, New York Sediment Criteria for metals and Provincial Sediment Quality Guidelines for metal contents in marine sediments. According to SQGs, more toxic metal is Cd followed by $\mathrm{As}$, and $\mathrm{Pb}$ respectively in terms of concentration which indicates that a high percentage of the concentration is likely to have adverse effects on sediment organisms. Metals concentration higher than ISQG-L level which indicates these elements probably have adverse effects on organisms that live in sediment.

It is observed that metal contents in sediments are fall under non-polluted category with respect to perceived metals but the concentration of Chromium and Mercury in few samples is nearing to threshold limit. This may be considered as a serious threat for aquatic organism and human being health. Present relative lower values could be due to the basic nature of the sediments and also due to great turbulence which basically restrict the accumulation of trace metals into the sediment. Therefore, it may be concluded that studied sediments are not contaminated in terms of studied heavy metals. Though the precise source of current metal inputs in the study area is accurately unknown and, hence requires further research. However, observed concentrations are believed to have perhaps been enriched through natural processes, industrial activities around the study area and polluted river water influx.

The results of this study supply valuable information about the metal contents in sediments from different sampling stations of the Mumbai High Region, Arabian Sea. This can be considered as a bio-indicator of the environmental contamination in this zone by estimating the bioavailability of metals to the marine biota.

Table 1 The coordinates of each Platforms

\begin{tabular}{|l|l|l|l|}
\hline Sr. No. & Platform & Latitude & Longitude \\
\hline 1 & R-12A & $18^{\circ} 16^{\prime} 20.32^{\prime \prime} \mathrm{N}$ & $72^{\circ} 22^{\prime} 48.52^{\prime \prime} \mathrm{E}$ \\
\hline 2 & BLQ & $19^{\circ} 12^{\prime} 16.80^{\prime \prime} \mathrm{N}$ & $72^{\circ} 6^{\prime} 27.00^{\prime \prime} \mathrm{E}$ \\
\hline 3 & NBP & $18^{\circ} 36^{\prime} 9.93^{\prime \prime} \mathrm{N}$ & $71^{\circ} 1^{\prime} 40.59^{\prime \prime} \mathrm{E}$ \\
\hline 4 & ICP & $19^{\circ} 20^{\prime} 30.00^{\prime \prime N}$ & $71^{\circ} 18^{\prime} 0.00^{\prime \prime} \mathrm{E}$ \\
\hline 5 & NQ & $19^{\circ} 34^{\prime} 15.00^{\prime \prime} \mathrm{N}$ & $71^{\circ} 21^{\prime} 32.40^{\prime \prime} \mathrm{E}$ \\
\hline
\end{tabular}


Table 2 Average metal concentration in ppm (mg kg-1) of each Platforms

\begin{tabular}{|c|c|c|c|}
\hline Station & ${ }^{\mathbf{7 5}} \mathbf{A s}$ & ${ }^{111} \mathbf{C d}$ & ${ }^{\mathbf{2 0 8} \mathbf{P b}}$ \\
\hline R-12A & 4.16 & 0.08 & 1.92 \\
\hline BLQ & 9.35 & 0.11 & 10.45 \\
\hline NBP & 5.05 & 0.06 & 1.94 \\
\hline ICP & 8.54 & 0.11 & 2.97 \\
\hline NQ & 7.87 & 0.15 & 9.29 \\
\hline
\end{tabular}

Table 3 Comparison of average concentration heavy metals obtained in this research with Sediment Quality Guidelines

\begin{tabular}{|c|c|c|c|}
\hline Sediment Quality Standard / Element & ${ }^{75} \mathrm{As}$ & ${ }^{208} \mathbf{P b}$ & ${ }^{111} \mathrm{Cd}$ \\
\hline Present Study & $4.16-9.35$ & $1.92-10.45$ & $0.08-0.15$ \\
\hline \multicolumn{4}{|l|}{ EPA Sediment Quality proposed } \\
\hline Non-Polluted & --- & $<40$ & --- \\
\hline Slightly Polluted & & $40-60$ & \\
\hline Severely Polluted & --- & $>60$ & $>6$ \\
\hline \multicolumn{4}{|l|}{ CBSOG SQG*(2003) } \\
\hline Non-Polluted & $<9.8$ & $<40$ & $<0.99$ \\
\hline Moderately Polluted & $9.8-21.4$ & $40-70$ & $0.99-3$ \\
\hline Heavily Polluted & $>21.4$ & $>70$ & $>3$ \\
\hline \multicolumn{4}{|l|}{ New York Sediment Criteria } \\
\hline Lowest effects range & 6 & 32 & 0.6 \\
\hline Sever effects range & 33 & 110 & 9 \\
\hline \multicolumn{4}{|c|}{ Sediment Quality Criteria Guidelines(1992)** } \\
\hline Lowest effects range(ISQG-low) & 6 & 31 & 0.6 \\
\hline High effects range(ISQG-high) & 33 & 250 & 10 \\
\hline Safe limit of Dutch guidelines ${ }^{* * *}$ & 55 & 530 & 12 \\
\hline Oman Gulf ${ }^{* * * *}$ & 15.1 & 11.62 & 5.02 \\
\hline
\end{tabular}

(Source: International Journal of Environmental, Chemical, Ecological, Geological and Geophysical Engineering Vol: 5, No: 2, 2011); *Consensus-Based Sediment Quality Guidelines (CBSOG) SQG (2003); **Interim marine Sediment Quality Criteria Guidelines (ISQG) (1992); ***Environmental Contamination and Assessment of Heavy Metals in Water, Sediments and Shrimp of Red Sea Coast of Jizan, Saudi Arabia M Golam Mortuza and Fahad A Al-Misned; ****Environmental Assessment of Heavy Metals Contamination of Bottom Sediments of Oman Gulf, United Arab Emirates El Tokhi M, Amin BM* and Alaabed SA 
Table 4 Heavy Metals in Sediments (mg/kg) around Installation R-12A

\begin{tabular}{|c|c|c|c|c|}
\hline Distance & Direction & ${ }^{75} \mathrm{As}$ & ${ }^{111} \mathrm{Cd}$ & ${ }^{208} \mathrm{~Pb}$ \\
\hline & & 4.50 & 0.03 & 0.76 \\
\hline & W & 4.29 & 0.06 & 2.03 \\
\hline & So & 5.62 & 0.10 & 2.21 \\
\hline & $\mathrm{N}$ & 4.10 & 0.00 & 0.34 \\
\hline \multirow{4}{*}{$0.50 \mathrm{~km}$} & $\mathrm{E}$ & 4.50 & 0.05 & 0.60 \\
\hline & W & 4.57 & 0.06 & 2.05 \\
\hline & So & 5.85 & 0.05 & 2.29 \\
\hline & $\mathrm{N}$ & 5.08 & 0.10 & 2.31 \\
\hline \multirow{4}{*}{$1.00 \mathrm{~km}$} & $\mathrm{E}$ & 4.49 & 0.01 & 0.45 \\
\hline & W & 2.47 & 0.02 & 0.30 \\
\hline & So & 3.34 & 0.09 & 1.59 \\
\hline & $\mathrm{N}$ & 4.62 & 0.10 & 2.22 \\
\hline \multirow{4}{*}{$2.00 \mathrm{~km}$} & $\mathrm{E}$ & 5.09 & 0.13 & 2.19 \\
\hline & W & 2.99 & 0.06 & 1.41 \\
\hline & So & 4.34 & 0.10 & 2.53 \\
\hline & $\mathrm{N}$ & 2.73 & 0.30 & 9.38 \\
\hline $4 \mathrm{Km}$ & $\mathrm{N}$ & 4.08 & 0.07 & 1.12 \\
\hline $10 \mathrm{Km}$ & & 2.15 & 0.07 & 0.77 \\
\hline
\end{tabular}

Table 5 Heavy Metals in Sediments $(\mathrm{mg} / \mathrm{kg}$ ) around Installation BLQ

\begin{tabular}{|l|l|l|l|l|}
\hline Distance & Direction & ${ }^{75} \mathbf{A s}$ & ${ }^{111} \mathbf{C d}$ & ${ }^{208} \mathbf{P b}$ \\
\hline \multirow{5}{*}{$0.25 \mathrm{~km}$} & E & 7.04 & 0.13 & 8.33 \\
\cline { 2 - 5 } & W & 7.68 & 0.15 & 8.02 \\
\cline { 2 - 5 } & So & 10.44 & 0.10 & 10.54 \\
\cline { 2 - 5 } & N & 11.58 & 0.10 & 13.43 \\
\hline \multirow{5}{*}{$0.50 \mathrm{~km}$} & E & 6.35 & 0.11 & 8.34 \\
\cline { 2 - 5 } & W & 7.75 & 0.12 & 10.06 \\
\cline { 2 - 5 } & So & 9.83 & 0.13 & 11.15 \\
\cline { 2 - 5 } & N & 9.87 & 0.07 & 10.87 \\
\hline \multirow{5}{*}{$1.00 \mathrm{~km}$} & E & 6.98 & 0.08 & 8.88 \\
\cline { 2 - 5 } & W & 8.81 & 0.14 & 11.17 \\
\cline { 2 - 5 } & So & 10.60 & 0.08 & 11.24 \\
\cline { 2 - 5 } & N & 10.49 & 0.17 & 11.30 \\
\hline \multirow{3}{*}{$2.00 \mathrm{~km}$} & E & 7.53 & 0.10 & 8.07 \\
\cline { 2 - 5 } & W & 10.97 & 0.08 & 11.70 \\
\cline { 2 - 5 } & So & 11.34 & 0.11 & 11.21 \\
\cline { 2 - 5 } & N & 9.67 & 0.07 & 11.29 \\
\hline $4 \mathrm{Km}$ & N & 10.68 & 0.03 & 10.45 \\
\hline $10 \mathrm{Km}$ & & 10.67 & 0.14 & 12.11 \\
\hline \multirow{5}{*}{} & & & \\
\hline & & & \\
\hline
\end{tabular}


Table 6 Heavy Metals in Sediments (mg/kg) around Installation NBP

\begin{tabular}{|c|c|c|c|c|}
\hline Distance & Direction & ${ }^{75}$ As & ${ }^{111} \mathrm{Cd}$ & ${ }^{208} \mathrm{~Pb}$ \\
\hline \multirow[t]{4}{*}{$0.25 \mathrm{~km}$} & $\mathrm{E}$ & 4.26 & 0.08 & 1.61 \\
\hline & $\mathrm{W}$ & 4.95 & 0.12 & 1.82 \\
\hline & So & 6.45 & 0.08 & 1.97 \\
\hline & $\mathrm{N}$ & 5.29 & 0.05 & 2.09 \\
\hline \multirow[t]{4}{*}{$0.50 \mathrm{~km}$} & $\mathrm{E}$ & 4.57 & 0.03 & 1.64 \\
\hline & $\mathrm{W}$ & 4.22 & 0.02 & 1.80 \\
\hline & So & 6.72 & 0.08 & 2.38 \\
\hline & $\mathrm{N}$ & 4.24 & 0.03 & 1.63 \\
\hline \multirow[t]{4}{*}{$1.00 \mathrm{~km}$} & $\mathrm{E}$ & 5.70 & 0.08 & 1.78 \\
\hline & W & 6.46 & 0.02 & 2.05 \\
\hline & So & 4.01 & 0.02 & 1.75 \\
\hline & $\mathrm{N}$ & 5.38 & 0.05 & 2.19 \\
\hline \multirow[t]{4}{*}{$2.00 \mathrm{~km}$} & $\mathrm{E}$ & 4.87 & 0.07 & 2.08 \\
\hline & W & 4.48 & 0.11 & 1.79 \\
\hline & So & 5.01 & 0.05 & 2.43 \\
\hline & $\mathrm{N}$ & 3.36 & 0.04 & 1.69 \\
\hline $4 \mathrm{Km}$ & $\mathrm{N}$ & 5.54 & 0.08 & 1.95 \\
\hline $10 \mathrm{Km}$ & & 5.30 & 0.02 & 2.29 \\
\hline
\end{tabular}

Table 7 Heavy Metals in Sediments (mg/kg) around Installation ICP

\begin{tabular}{|c|c|c|c|c|}
\hline Distance & Direction & ${ }^{75} \mathrm{As}$ & ${ }^{111} \mathrm{Cd}$ & ${ }^{208} \mathrm{~Pb}$ \\
\hline \multirow[t]{4}{*}{$0.25 \mathrm{~km}$} & $\mathrm{E}$ & 7.68 & 0.14 & 2.46 \\
\hline & $\mathrm{W}$ & 7.34 & 0.09 & 2.37 \\
\hline & So & 7.52 & 0.09 & 3.09 \\
\hline & $\mathrm{N}$ & 10.36 & 0.10 & 3.83 \\
\hline \multirow[t]{4}{*}{$0.50 \mathrm{~km}$} & $\mathrm{E}$ & 8.28 & 0.08 & 2.27 \\
\hline & $\mathrm{W}$ & 8.95 & 0.16 & 4.04 \\
\hline & So & 9.91 & 0.10 & 3.64 \\
\hline & $\mathrm{N}$ & 7.01 & 0.08 & 2.66 \\
\hline \multirow[t]{4}{*}{$1.00 \mathrm{~km}$} & $\mathrm{E}$ & 6.47 & 0.13 & 2.75 \\
\hline & $\mathrm{W}$ & 7.85 & 0.09 & 2.45 \\
\hline & So & 10.09 & 0.12 & 3.78 \\
\hline & $\mathrm{N}$ & 11.80 & 0.10 & 3.72 \\
\hline \multirow[t]{4}{*}{$2.00 \mathrm{~km}$} & $\mathrm{E}$ & 7.01 & 0.15 & 2.20 \\
\hline & $\mathrm{W}$ & 9.42 & 0.09 & 3.38 \\
\hline & So & 6.75 & 0.10 & 2.50 \\
\hline & $\mathrm{N}$ & 8.12 & 0.11 & 2.29 \\
\hline $4 \mathrm{Km}$ & $\mathrm{N}$ & 9.65 & 0.08 & 3.11 \\
\hline $10 \mathrm{Km}$ & & 9.56 & 0.11 & 2.88 \\
\hline
\end{tabular}


Table 8 Heavy Metals in Sediments $(\mathrm{mg} / \mathrm{kg})$ around Installation NQ

\begin{tabular}{|l|l|l|l|l|}
\hline Distance & Direction & ${ }^{75} \mathbf{A s}$ & $\mathbf{1 1 1} \mathbf{C d}$ & ${ }^{208} \mathbf{P b}$ \\
\hline $0.25 \mathrm{~km}$ & E & 7.92 & 0.14 & 10.48 \\
\cline { 2 - 5 } & W & 7.45 & 0.19 & 9.75 \\
\cline { 2 - 5 } & So & 7.84 & 0.16 & 9.09 \\
\cline { 2 - 5 } & N & 7.21 & 0.15 & 8.20 \\
\hline $0.50 \mathrm{~km}$ & E & 7.82 & 0.14 & 9.94 \\
\cline { 2 - 5 } & W & 7.57 & 0.11 & 9.32 \\
\cline { 2 - 5 } & So & 9.26 & 0.16 & 9.95 \\
\cline { 2 - 5 } & N & 8.07 & 0.16 & 9.50 \\
\hline $1.00 \mathrm{~km}$ & E & 7.90 & 0.16 & 9.28 \\
\cline { 2 - 5 } & W & 7.81 & 0.13 & 8.25 \\
\cline { 2 - 5 } & So & 8.67 & 0.12 & 10.15 \\
\cline { 2 - 5 } & N & 7.65 & 0.17 & 9.25 \\
\hline $2.00 \mathrm{~km}$ & E & 7.26 & 0.16 & 9.16 \\
\cline { 2 - 5 } & W & 7.95 & 0.21 & 9.36 \\
\cline { 2 - 5 } & So & 7.46 & 0.15 & 7.63 \\
\cline { 2 - 5 } & N & 8.80 & 0.17 & 9.71 \\
\hline $4 \mathrm{Km}$ & N & 8.16 & 0.11 & 10.00 \\
\hline $10 \mathrm{Km}$ & & 6.86 & 0.12 & 8.15 \\
\hline
\end{tabular}

\section{Conclusion}

The results of present study emphasize that heavy metal $\left({ }^{75} \mathrm{As},{ }^{111} \mathrm{Cd}\right.$ and $\left.{ }^{208} \mathrm{~Pb}\right)$ concentrations in sediments of 5 platforms (R-12A, BLQ NBP, ICP and NQ) of Mumbai High Region, Arabian Sea were on absolutely lower side and well comparable with the reported values of available oceanographic scientific literature. This can be thought to have resulted from absence of significant anthropogenic influence around the study area. In relation to this, the low metal contents found in all the studied sediment samples are insufficient to cause any toxicological effects on human health when seafood is included in the diet. Therefore, sediments in present study area in Bay of Bengal are not polluted with respect to heavy metals but requires regular monitoring of marine environment, particularly zones where industrial operations are planned.

\section{Compliance with ethical standards}

\section{Acknowledgments}

The authors are grateful to the ONGC's management for encouraging for preparation and presentation of this paper. They also wish to acknowledge ED-HoI, IPSHEM for his continuous guidance and support.

Authors are also honestly grateful to Shri R K Srivastava, Director (Exploration), ONGC, for his encouragement for preparation of this paper.

\section{Disclosure of conflict of interest}

The authors declare no conflict of interest.

\section{References}

[1] IPSHEM, ONGC. Offshore Environmental Monitoring Projects of Western Offshore Region 2019-20 (Unpublished reports). 
[2] OSPAR Guidelines for Monitoring the Environmental Impact of Offshore Oil and Gas Activities, 2004-11.

[3] Xin Jiang, et al, Distribution and pollution assessment of heavy metals in surface sediments in the Yellow Sea, Marine Pollution Bulletin 2014; 83:366-375.

[4] Feng Ye, et al, Distribution of heavy metals in sediments of the Pearl River Estuary, Southern China: Implications for sources and historical changes, Journal of Environmental Sciences 2012; 24:1-10.

[5] Hasrizal Shaari, et al, Spatial Distribution of Selected Heavy Metals in Surface Sediments of the EEZ of the East Coast of Peninsular Malaysia, International Journal of Oceanography, Volume 2015, Article ID 618074.

[6] OJ Aderinola, et al, Heavy Metals in Surface Water, Sediments, Fish and Perwinklesof Lagos Lagoon, AmericanEurasian J. Agric. \& Environ. Sci., 20095; (5):609-617, ISSN 1818-6769.

[7] Sukalyan Chakraborty, et al, Benthic macroalgae as biological indicators of heavy metal pollution in the marine environments: A biomonitoring approach for pollution assessment, Ecotoxicology and Environmental Safety 100 2014; 61-68.

[8] Rui Zhang, et al, Heavy metal pollution and assessment in the tidal flat sediments of Haizhou Bay, China, Marine Pollution Bulletin 2013; 74:03-412.

[9] AW Muohi, et al, Heavy metals in sediments from Makupa and Port-Reitz Creek systems: Kenyan Coast, Environment International 2003; 28:639- 647.

[10] N Balkıs, et al, Heavy metals in shallow sediments from the Black Sea, Marmara Sea and Aegean Sea regions of Turkey, J. Black Sea/Mediterranean Environment, 2007; Vol. 13:147-153.

[11] G Suresh, et al, Spatial and vertical distributions of heavy metals and their potential toxicity levels in various beach sediments from high-background-radiation area, Kerala, India, Marine Pollution Bulletin 2015; 91:389400 .

[12] Humood A Naser, Assessment and management of heavy metal pollution in the marine environment of the Arabian Gulf: A review, Marine Pollution Bulletin 2013; 72:6-13.

[13] Henry Vallius, et al, Classification of heavy metal contaminated sediments of the Gulf of Finland, Baltica 2003 ;16:3-12.

[14] BTavakoly Sany, et al, Assessment of Sediment Quality According to Heavy Metal Status in the West Port of Malaysia, International Journal of Environmental, Chemical, Ecological, Geological and Geophysical Engineering Vol:5:No:2:201 